\title{
CHEMICAL COMPOSITIONS OF COEXISTING BIOTITES AND HORNBLENDES FROM OKUEYAMA GRANODIORITE, KYUSHU, JAPAN
}

\author{
TAKanobu OBa \\ Department of Geology and Mineralogy, Facully of Science, Hokkaido University, Sapporo \\ Masahiko Yamamoto and Noboru Öba \\ Institute of Earth Sciences, Faculty of Science, Kagoshima University, Kagoshima
}

\begin{abstract}
Chemical compositions of coexisting bjotites and hornblendes and their host rocks of the Shishigawa-type of the Okueyama granodiorite batholith were investigated. Compositional difference which can be seen between granitic rocks of the southern part and those of the northern part in the batholith indicates that the rocks of the latter were affected by a residual liquid due to differentiation of magma of the main body of the Okueyama granodiorite. Both biotites and hornblendes are poor in $\mathrm{Al}$, and low in $\mathrm{Mg} / \mathrm{Fe}^{+2}$ ratio. The distribution coefficient for $\mathrm{Mg}$ and $\mathrm{Fe}^{+2}$ of the coexisting biotite and hornblende pairs is 0.75 in average. Comparing with chemical compositions of coexisting biotite and hornblende pairs from granitic rocks in Kitakami and Ryoke regions, those of coexisting biotite and hornblende pairs from the Okueyama granodiorite suggest that rocks of the Okueyama main body would have been formed as a volcano-plutonic complex.
\end{abstract}

\section{INTRODUCTION}

Many bodies of Tertiary granitic intrusives are distributed in South Kyushu. Granitic rocks carrying both biotite and hornblende are, in general, exposed in the northern belt of the Shimanto terrain. It is known that these granitic rocks were formed in a state of the volcano-plutonic activities at relatively shallow depths. Therefore, it is interested to investigate the physical and chemical natures of the coexisting biotite and hornblende pairs.

The Okueyama granodiorite batholith is located in the northern belt of the Shimanto terrain, Miyazaki Prefecture, Japan (Fig. 1). Geological and petrological studies of this batholith and the surrounding area have been reported by Toriyama (1936),
Kuroda (1948), Hashimoto and Miyahisa (1959), Nozawa and Takahashi (1960), and Ōba (1961). This paper presents physical and chemical natures of coexisting biotites and hornblendes from the Shishigawa-type granitic rocks which occupy the southwestern part of the batholith. An attempt is made to compare chemical compositions of the coexisting biotite and hornblende pairs from rocks of this batholith to those of coexisting biotite and hornblende pairs from Kitakami and Ryoke granitic rocks.

\section{Geologic Relations of the OKue- YAMA GgRANODIORITE BATHOLITH}

Geology of the Shishigawa district is shown in Fig. 1. The Okueyama granodiorite batholith intrudes the geosynclinal 

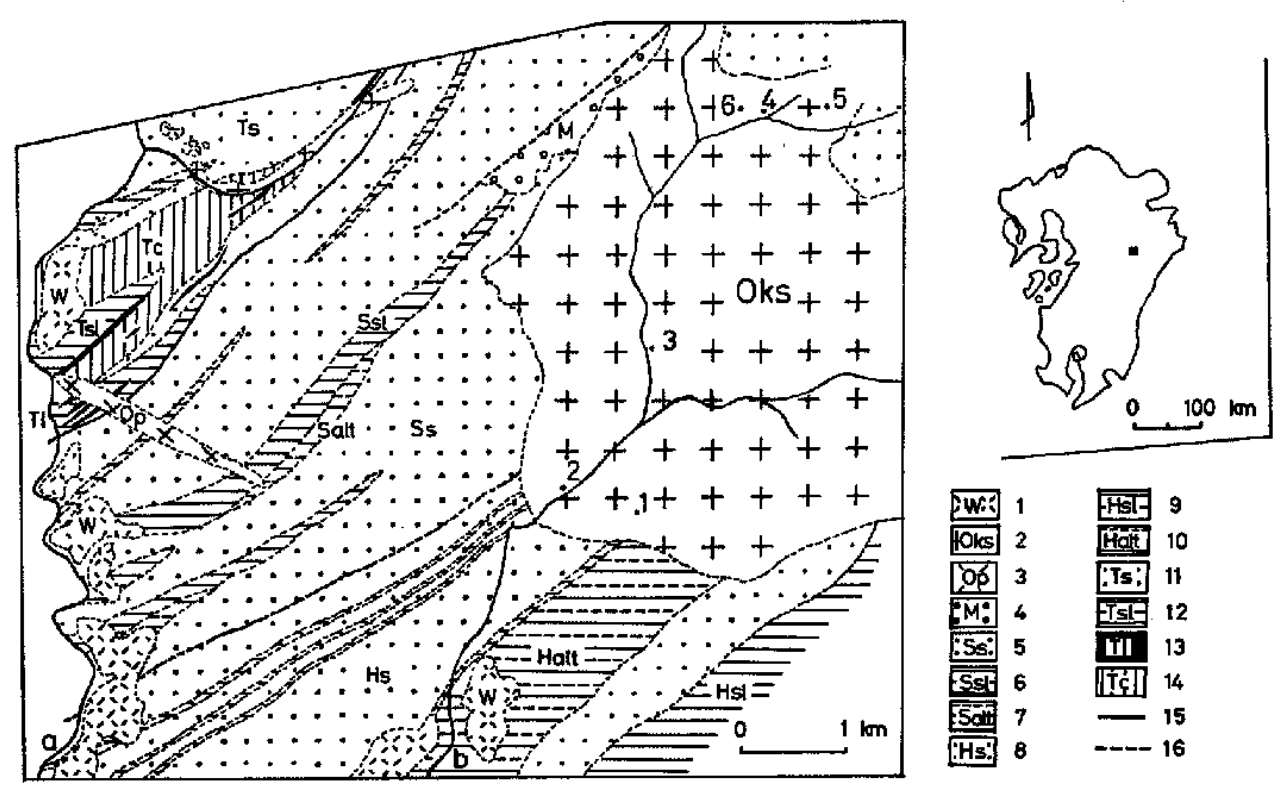

\begin{tabular}{|c|c|c|}
\hline EW: & & 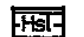 \\
\hline HOKS & 2 & Holiti \\
\hline कó & 3 & Ts: \\
\hline $\mathrm{FM}$ & 4 & ETSI]-1 \\
\hline $.5 s$ & 5 & |il \\
\hline Sist & 6 & |İE \\
\hline 5 & 7 & -1 \\
\hline :H & 8 & \\
\hline
\end{tabular}

Fig. 1. Index and geologic maps of the southwestern part of the Okueyama granodiorite, Miyazaki Prefecture. Map showing the distribution of the granodiorite and the collected points of the analysed samples.

Stratigraphic sequence: 1. Aso welded-tuff, 2 and 3. Okueyama granodiorite (2. Shishigawa-type granodiorite 3. granite porphyry). 4. Mitate conglomerate. 5, 6 and 7. Shiiba, formation (5. Sandstone, 6. Clayslate, 7. Alternation of sandstone and clayslate). 8,9 and 10. Hinokage formation (8. Sandstone, 9. Clayslate, 10. Alternation of sandstone and clayslate). 11, 12, 13 and 14. Togawa formation (11. Sandstone, 12. Clayslate, 13. Limestone, 14. Chert).

Faults 15. Fault. 16. Inferred fault.

Location a, Hinokage-gawa. b. Aminoshe-gawa.

sedimentary rocks of the Chichibu and Shimanto terrains. In the Chichibu terrain, only the Togawa Formation of the Permian age, which is composed mainly of sandstone, clayslate and chert with lenses of limestone and thin layers of conglomerate, is distributed in the northern part of the district. In the Shimanto terrain of the district, the Shimanto Group of the certain age (probably Jurassic to Cretaceous) is divided into the following two formations by a fault: one is the Hinokage Formation composed mainly of sandstone and alternation of sandstone and claystate, and the other is the Shiba Formation consisting of sandstone with alternation of sandstone and claylsate (Imai et al. 1971). The Chichibu and the Shimanto Groups are geologic members widely distributed in the Outer Zone of Southwest Japan. Both Groups are bounded by the Butsuzo tectonic line from each other, and show a conspicuous zonal arrangement of rocks with northeast-southwest trend.

The Mitate conglomerate of the Paleogene age which is distributed in the northwestern part of the batholith, is unconformably overlain by the Shimanto Group, and comprises gravels of chert and sandstone with partly pelitic rocks. The Pleistocene Aso welded tuff derived from the Aso caldera occurs in small areas along the Aminose and the Hinokage rivers, and unconformably 
overlain by the Togawa Formation and the Shimanto Group.

\section{The OKueyama Granodiorite Ba- THOLITH}

The Okueyama granodiorite batholith is exposed in $10 \mathrm{~km}$ in the length diameter, and intrudes the Togawa Formation, the Shimanto Group and the Mitate conglomerate. Roof pendants of the Shimanto Group occur in some places. Ring dikes and satellitic bodies, composed of granite porphyry and quartz porphyry, occur around the batholith. The boundaries between the batholith and the adjacent surrounding sedimentary rocks show sharp and discordant contacts, and indicate that the initial form at the time when the batholith was formed is considerably preserved well up to the present time. Greisen and tourmaline deposits are found in the contacts in the northern part of the batholith. In the adjacent areas surrounding the batholith, biotite and cordierite as contact minerals are contained in thermally metamorphosed pelitic rocks, and garnet in thermally metamorphosed calcareous rocks of the Togawa Formation. Skarn minerals such as garnet and pyroxene are found within the Chichibu terrain. Many ore deposits can be observed in the contact aureoles. Data of K-Ar and zircon ages (Miller et al., 1962 and Miyahisa et al, 1953) indicate that the batholith was formed in the Miocene age $(21 \pm 1 \mathrm{~m} . \mathrm{y}$.$) .$

Hashimoto and Miyahisa (1959) reported that the batholith was emplaced just after the activity of the Sobosan acidic volcanic rocks in the northwestern part of this district, and that the volcanic rocks can be correlated to the Ishizuchiyama acidic igneous complex in North Shikoku. They concluded that the Sobosan-Okueyama acidic volcanic and intrusive bodies are products of volcano-plutonic complex activities.

\section{Petrography and Petrochemistry OF THE GRaNITIC Rocks}

The Okueyama granodiorite is lithologically divided into two types of Shishigawa and Horigawa (Ōba, 1961). The rocks of Shishigawa-type, which are leucocratic and medium grained granodiorite with slightly porphyritic texture, intrude both the Shimanto Group and Mitate conglomerate (see Fig. 1). The rocks of this type consist mainly of biotite, green hornblende, orthoclase, plagioclase and quartz, and a small amount of zircon, magnetite and apatite are accompanied as accessories. Xenoliths of pelitic rock and basic rock origin are found throughout the batholith. Xenoliths measuring about $50 \mathrm{~cm}$ in diameter can be found in the northern part of the batholith, but those present abundantly in the southern part are less than $5 \mathrm{~cm}$ in size.

Plagioclase occurs as euhedral grains with commonly twinned on albite and Carlsbad laws and rarely on pericline law. Zoned plagioclase range in composition from $A n_{20}$ to $\mathrm{An}_{35}$ from the refractive indices (see Table 1). Myrmekite is sometimes observed in the margin of plagioclase grains. Quartz occurs as large porphyritic crystals or assemblage of small grains. Orthoclase occurring as anhedral to subhedral grains is commonly twinned on Carisbad and rarely perthite.

Biotite occurs as euhedral independent flakes with ragged edges. Sometimes, biotite which occurs together with hornblende shows glomeropophyritic texture, in which their grain boundaries are sharp or intertongued of biotite. Biotite is more than $3 \mathrm{~mm}$ in size and has pleochroism with 
$\mathrm{X}=$ light yellow and $\mathrm{Z}$ - deep brown to reddish brown. It is sometimes altered to chlorite. Zircon and magnetite are commonly found within biotite grains as inclusions. Biotite in xenoliths is much smaller, about $0.1 \mathrm{~mm}$ in length.

Hornblende occurs as subhedral grains and has pleochroism with $\mathrm{X}=$ light green and $Z=$ green. Twinning is sometimes found. Apatite and magnetite are common

Table 1. Chemical compositions of granitic rocks of the Shishigawa-type of the Okueyama batholith.

\begin{tabular}{|c|c|c|c|c|c|c|}
\hline No. & Oks -1 & $0 \mathrm{ks}-2$ & $0 \mathrm{ks}-3$ & $0 k s-4$ & $0 \mathrm{ks}-5$ & $0 \mathrm{ks}-6$ \\
\hline \multicolumn{7}{|c|}{ Modal analyses } \\
\hline Quartz & 23.9 & 30.3 & 21.7 & 29.5 & 37.1 & 32.8 \\
\hline K-feldspar & 22.3 & 22.6 & 26.9 & 25.0 & 28.4 & 23.9 \\
\hline Plagioclase & 37.3 & 31.4 & 36.6 & 33.2 & 28.2 & 33.7 \\
\hline Biotite & 8.5 & 12.7 & 12.9 & 3.7 & 8.4 & 7.7 \\
\hline Hornbiende & 7.5 & 2.1 & 1.0 & 0.2 & - & 1.8 \\
\hline Chlorite & 0.2 & 0.9 & 1.0 & 0.2 & tr. & 0.1 \\
\hline Others & tr. & tr. & tr. & tr. & tr. & tr. \\
\hline Total & 99.7 & 100.0 & 100.1 & 99.8 & 100.1 & 100.0 \\
\hline \multicolumn{7}{|c|}{ Chenical analyses* } \\
\hline $\mathrm{SiO}_{2}$ & 61.82 & 66.10 & 65.96 & 70.46 & 71.46 & 71.58 \\
\hline $\mathrm{TiO}_{2}^{2}$ & 0.44 & 0.33 & 0.30 & 0.19 & 0.29 & 0.15 \\
\hline $\mathrm{A}_{2} \mathrm{O}_{3}$ & 15.01 & 14.37 & 14.85 & 14.74 & 13.46 & 12.48 \\
\hline $\mathrm{Fe}_{2} \mathrm{O}_{3}$ & 1.73 & 1.85 & 1.77 & 0.84 & 0.80 & 0.51 \\
\hline $\mathrm{FeO}$ & 4.59 & 1.99 & 2.33 & 0.52 & 0.85 & 1.00 \\
\hline MnD & 0.13 & 0.06 & 0.03 & 0.06 & 0.08 & 0.10 \\
\hline $\mathrm{MgO}$ & 1.91 & 1.59 & 1.59 & 1.03 & 0.46 & 1.16 \\
\hline $\mathrm{CaO}$ & 3.62 & 3.16 & 3.03 & 2.73 & 1.13 & 3.13 \\
\hline $\mathrm{Na}_{2} \mathrm{O}$ & 4.60 & 3.30 & 2.40 & 3.40 & 2.20 & 4.01 \\
\hline$k_{2} 0$ & 3.40 & 3.50 & 4.00 & 3.20 & 5.60 & 3.70 \\
\hline $\mathrm{H}_{2} \mathrm{O}^{+}$ & 1.46 & 1.96 & 2.10 & 1.56 & 1.98 & 1.22 \\
\hline $\mathrm{H}_{2} \mathrm{O}^{-}$ & 0.78 & 1.58 & 1.38 & 1.84 & 1.28 & 0.52 \\
\hline $\mathrm{P}_{2} \mathrm{O}_{5}$ & 0.15 & 0.06 & 0.15 & 0.05 & 0.06 & 0.01 \\
\hline Tota1 & 99.67 & 99.85 & 99.85 & 99.92 & 99.63 & 99.57 \\
\hline \multicolumn{7}{|c|}{ CIPH nortis } \\
\hline$Q$ & 9.8 & 23.4 & 26.5 & 30.0 & 33.3 & 27.8 \\
\hline c & - & - & 1.6 & 1.0 & 2.2 & - \\
\hline Or & 20.7 & 21.7 & 24.9 & 79.6 & 35.0 & 22.5 \\
\hline$A b$ & 42.4 & 31.0 & 22.7 & 31.5 & 20.9 & 36.9 \\
\hline An & 10.0 & 14.7 & 15.0 & 13.7 & 5.4 & 3.1 \\
\hline Mt & 4.1 & 1.9 & 1.9 & 1.0 & 0.9 & 0.5 \\
\hline 11 & 0.6 & 0.5 & 0.5 & 0,3 & 0.4 & 0.2 \\
\hline Ap & 0.3 & 0.1 & 0.3 & 0.1 & 0.2 & 0.03 \\
\hline Di & 5.6 & 0.8 & - & - & - & 8.3 \\
\hline Hy & 8.3 & 5.7 & 5.7 & 3.0 & 1.9 & 0.3 \\
\hline 0.1. & 72.9 & 76.1 & 74.1 & 81.1 & 89.2 & 87.2 \\
\hline mg & 0.35 & 0.44 & 0.42 & 0.58 & 0.33 & 0.57 \\
\hline \multicolumn{7}{|l|}{ Plagloclase } \\
\hline \multirow[t]{2}{*}{ Index $n_{\boldsymbol{1}}$} & 1.546 & 1.545 & 1.540 & 1.538 & 1.540 & 3.538 \\
\hline & 1.556 & 1.555 & 1.545 & 1.548 & 1.547 & 1.549 \\
\hline An content & 35 & 32 & 23 & 20 & 23 & 21 \\
\hline
\end{tabular}

inclusions in hornblende.

Calcite is rarely found as accessory mineral within granitic rocks. The mode of occurrence of calcite indicates that calcite is not a product of hydrothermal alteration, but a primary mineral crystallized at the latest stage during the formation of the batholith.

Modal and chemical analyses of six rock samples of the Shishigawa-type, Nos. Oks1,2 and 3 , collected from the southern part of the batholith at the elevation of $600 \mathrm{~m}$ above sea level, and three rock samples from the northern part at the elevation of $1000 \mathrm{~m}$ (see Fig. 1) were made. These analytical data and CIPW norms are given in Table 1.

Color index ranges from 16 in rocks of the southern part to 6 in rocks of the northern part of the batholith, and the amount of hornblende decreases from the

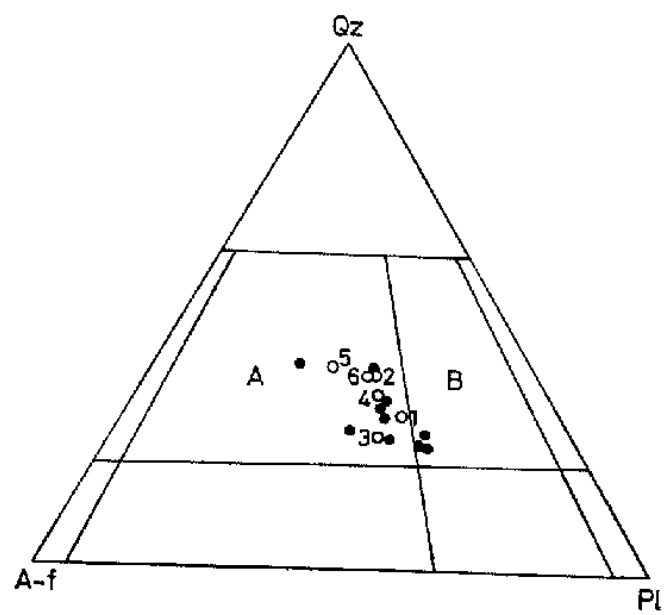

Fig. 2. Modal relation of plagioclase, alkalifeldsaprs and quartz. Showing classification of the IUGS subcommittee. A: Granite, B: Granodiorite 1; Hornblende biotite granite. 2; Hornblende biotite granite. 3 ; (augite bearing) hornblende biotite granite. 4; Hornblende bearing biotite granite. 5 ; Biotite granite. 6; Hornblende bearing biotite granite. 
former to the latter. Calcite was found only within the sample No. Oks -3 , which has the highest chlorite/(biotite+hornblende) ratio in mode as compared to the other samples. Fig. 2 shows modal composition of analyzed rock samples. Almost all of the analyzed samples are plotted within the granite field.

Differentiation indices range from 73 in rocks of the southern part to 89 in rocks of the northern part of the batholith. From the former to the latter, the contents of $\mathrm{MgO}$ and $\mathrm{CaO}$ regularly decrease, whereas those of $\mathrm{SiO}_{2}$ increase. Normative $\mathrm{Di}$ ranging from 5.6 to 0.8 in amount was calculated in rock samples, Nos. Oks-1, 2 and 6, which indicate that the rocks of the southern part of the batholith are not rich in $\mathrm{Al}_{2} \mathrm{O}_{3}$. The $\mathrm{K}_{2} \mathrm{O} / \mathrm{Na}_{2} \mathrm{O}$ ratios range from 0.74 to 2.5 , and the $\mathrm{FeO} / \mathrm{CaO}$ ratios from 1.3 to 0.2 , which are consistent with the general petrological features of granitic rocks in the western district of the Shimanto terrain reported by Ōba (1967). On the evolution trend diagram, $\left(\mathrm{FeO}+\mathrm{Fe}_{2} \mathrm{O}_{3}\right)-\left(\mathrm{Na}_{2} \mathrm{O}+\mathrm{K}_{2} \mathrm{O}\right)-$

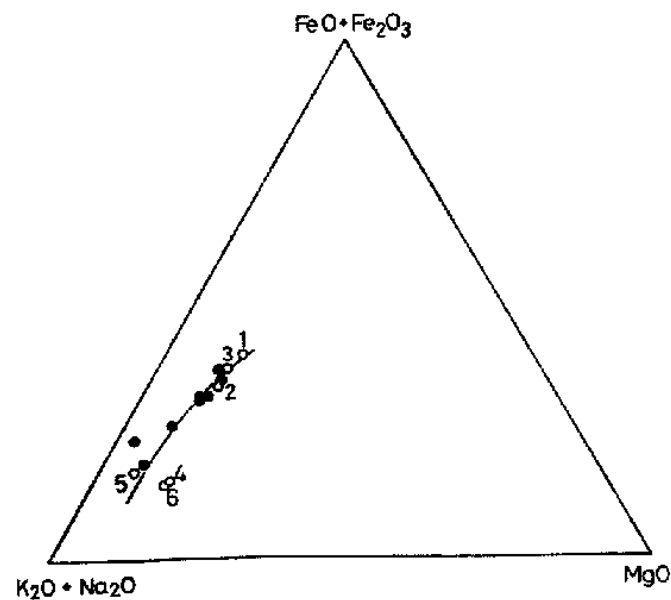

Fig. 3 Evolution-trend diagram, $\left(\mathrm{FeO}+\mathrm{Fe}_{2} \mathrm{O}_{9}\right)-$ $\left(\mathrm{K}_{2} \mathrm{O}+\mathrm{Na}_{2} \mathrm{O}\right)-\mathrm{MgO}$. Solid line; Variation trend curve showing the Southwestern Outer Zone granites. ; Nozawa and Takahashi, 1960. O; This papers.
$\mathrm{MgO}$, Fig. 3, solid curve represents a variation trend-curve showing the Southwestern Outer Zone granites (Öba, 1961). The plotted points of the analyzed rocks in this paper fall on the solid curve.

\section{Ghemical Composition of Biotites}

Five biotites were separated from the pulvarized rock samples by means of a magnetic separator and heavy liquid. Their chemical compositions are listed in Table 2 together with structural formulas calculated on the basis of $24(\mathrm{O}, \mathrm{OH})$ and optical properties.

Table 2, Chemical compositions of biotites from granitic rocks of the Shishigawa-type of the Okueyama batholith.

\begin{tabular}{|c|c|c|c|c|c|}
\hline No. & $0 \mathrm{ks}-1$ & $0 \mathrm{ks}-2$ & $0 \mathrm{ks}-3$ & $0 \mathrm{ks}-4$ & Oks-5 \\
\hline \multicolumn{6}{|c|}{ Chemical analyses } \\
\hline $\mathrm{Sin}_{2}$ & 35.98 & 34.96 & 35.02 & 35.36 & 35.72 \\
\hline $\mathrm{TiO}_{2}^{\mathrm{C}}$ & 3.66 & 3.66 & 3.58 & 3.56 & 2.32 \\
\hline $\mathrm{A}_{2} \mathrm{O}_{3}$ & 12.29 & 12.98 & 12.68 & 12.74 & 14.19 \\
\hline $\mathrm{Fe}_{2} \mathrm{O}_{3}$ & 4.36 & 4.98 & 5.56 & 5.73 & 3.48 \\
\hline $\mathrm{FeO}$ & 20.48 & 19.22 & 19.31 & 19.94 & 22.82 \\
\hline MgO & 7.24 & 7.66 & 8.31 & 8.30 & 5.91 \\
\hline Mno & 0.35 & 0.29 & 0.30 & 0.29 & 0.75 \\
\hline $\mathrm{CaO}$ & 1.26 & 1.03 & 0.50 & 0.41 & 0.35 \\
\hline $\mathrm{Na}_{2} \mathrm{O}$ & 0.30 & 0.50 & 0.20 & 0.30 & 0.70 \\
\hline $\mathrm{K}_{2} \mathrm{D}$ & 7.20 & 8.00 & 7.50 & 6.70 & 7.15 \\
\hline $\mathrm{H}_{2}^{2} \mathrm{O}^{+}$ & 4.76 & 4.46 & 4.52 & 4,62 & 4.28 \\
\hline $\mathrm{H}_{2}^{-} \mathrm{O}^{-}$ & 1.53 & 2.32 & 2.37 & 1.66 & 1.65 \\
\hline $\mathrm{P}_{2} \mathrm{O}_{5}$ & 0.04 & 0.01 & 0.02 & 0.03 & 0.09 \\
\hline Total & 99.45 & 100.07 & 99.87 & 100.64 & 99.40 \\
\hline \multicolumn{6}{|c|}{ Structural formulae. } \\
\hline $5 i$ & 5.589 & 5.473 & 5.481 & 5.488 & 5.626 \\
\hline AI IV & 2.249 & 2.398 & 2.331 & 2.329 & 2.374 \\
\hline $\mathrm{Fe}^{+3}$ & 0.162 & 0.129 & 0.188 & 0.183 & - \\
\hline z & B. 000 & 8.000 & B. 000 & 8.000 & a.000 \\
\hline$A I^{V I}$ & - & - & - & - & 0.255 \\
\hline $\mathrm{Ti}$ & 0.438 & 0.437 & 0.427 & 0.422 & 0.278 \\
\hline $\mathrm{Fe}^{+3}$ & 0.351 & 0.454 & 0.470 & 0.488 & 0.416 \\
\hline $\mathrm{Fe}^{+2}$ & 2.659 & 2.520 & 2.519 & 2.590 & 3.007 \\
\hline $\mathrm{Mg}$ & 1.680 & 1.787 & 1.937 & 1.910 & 1.390 \\
\hline $\mathrm{Mn}$ & 0.047 & 0.038 & 0.038 & 0.037 & 0.104 \\
\hline$Y$ & 5.175 & 5.236 & 5.391 & 5.447 & 5.450 \\
\hline $\mathrm{Ca}$ & 0.205 & 0.169 & 0.075 & 0.065 & 0.057 \\
\hline $\mathrm{Na}$ & 0.093 & 0.150 & 0.056 & 0.093 & 0.217 \\
\hline K & 1.428 & 1.599 & 1.485 & 1.322 & 1.437 \\
\hline$x$ & 1.726 & 1.918 & 1.626 & 1.480 & 1.771 \\
\hline $\mathrm{OH}$ & 4.936 & 4.664 & 4.719 & 4.780 & 4.501 \\
\hline$m g$ & 0.345 & 0.365 & 0.378 & 0.370 & 0.285 \\
\hline $\mathrm{Mg} / \mathrm{Fe}^{+2}$ & 0.63 & 0.71 & 0.77 & 0.74 & 0.46 \\
\hline index $B$ & 1.649 & 1.658 & 1.647 & 1.660 & 1.652 \\
\hline
\end{tabular}




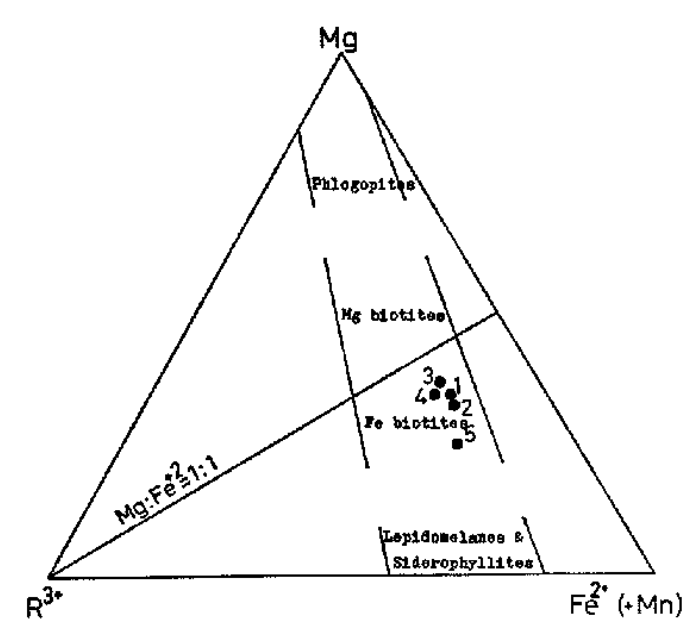

Fig. 4 Relation between $\mathrm{Mg}, \mathrm{Fe}^{+2}\left(+\mathrm{Mn}^{+2}\right), \mathrm{R}^{+8}$ (A1, $\mathrm{Fe}^{+3}$ and $\mathrm{Ti}$ ) in trioctahedral micas after M.D.Forster (1960).

Relations among octahedral members in the structural formulas of analyzed biotites are shown in Fig. $4, \mathrm{Mg}^{-\mathrm{R}^{+3}}\left(\mathrm{Al}^{\mathrm{VI}}+\mathrm{Ti}+\right.$ $\left.\mathrm{Fe}^{+3}\right)-\left(\mathrm{Fe}^{+2}+\mathrm{Mn}\right.$ ) (Foster, 1960). All the biotites fall within the $\mathrm{Fe}^{+2}$-biotite field, and are plotted in parallel to the $\mathrm{Mg}-\left(\mathrm{Fe}^{+2}+\mathrm{Mn}\right)$ line, indicating the compositional variation between $\mathrm{Mg}$ and $\mathrm{Fe}^{+2}$. The $\mathrm{Mg} / \mathrm{Fe}^{+2}$ ratios range from 0.46 to 0.77 . No $\mathrm{Al}^{\mathrm{vI}}$ or only small amount of $\mathrm{Al}^{\mathrm{VI}}$ was calculated in biotites from rocks containing both biotite and hornblende unaffected by residual liquid. This fact is consistent with chemical composition of some host granodiorite in which normative Di appears. On the other hand, $\mathrm{Al}^{\mathrm{vI}}$ of 0.26 per formula unit was calculated in biotite from rock free from hornblende affected by the residual liquid.

\section{Chemical COMPOSITION OF HORNBL- ENDES}

Four hornblendes separated from the host rocks were chemically analysed. The chemical analyses, structural formulas calculated on the basis of $24(\mathrm{O}, \mathrm{OH})$, and
Table 3. Chemical compositions of hormblendes from granitic rocks of the Okeuyama batholith.

\begin{tabular}{|c|c|c|c|c|}
\hline No. & Oks-1 & Oks-2 & $0 \mathrm{ks}-3$ & $0 \mathrm{kss}-4$ \\
\hline \multicolumn{5}{|c|}{ Chemical analyses* } \\
\hline $\mathrm{SiO}_{2}$ & 44.97 & 45.98 & 45.84 & 47.97 \\
\hline $\mathrm{TiO}_{2}$ & 2.31 & 9.67 & 2.02 & 0,94 \\
\hline $\mathrm{A}_{2} \mathrm{~B}_{3}$ & 6.40 & 6.65 & 5.86 & 4.85 \\
\hline $\mathrm{Fe}_{2} \mathrm{O}_{3}$ & 4.20 & 3.64 & 2.85 & 3.21 \\
\hline $\mathrm{FeO}$ & 19.58 & 18.05 & 19.22 & 18.53 \\
\hline MgO & 9.14 & 9.81 & 9.15 & 10.13 \\
\hline MnO & 0.71 & 0.59 & 0.74 & 0.77 \\
\hline $\mathrm{CaO}$ & 9.30 & 9.32 & 11.37 & 10.85 \\
\hline $\mathrm{Na}_{2} \mathrm{O}$ & 3.28 & 1.40 & 1.02 & 0.91 \\
\hline $\mathrm{K}_{2} \mathrm{D}$ & 0.57 & 0.95 & 0.47 & 0.33 \\
\hline $\mathrm{H}_{2}^{*} \mathrm{O}^{*}$ & 1.96 & 1.76 & 1.94 & 1.88 \\
\hline $\mathrm{H}_{2} \mathrm{O}^{-}$ & 0.12 & 0.32 & 0.06 & 0.16 \\
\hline $\mathrm{P}_{2} \mathrm{O}_{5}$ & 0.02 & 0.03 & 0.02 & - \\
\hline Total & 100.56 & 100.17 & 100.55 & 100.53 \\
\hline \multicolumn{5}{|c|}{ Structural formulae } \\
\hline $\mathrm{Si}$ & 6.830 & 6.977 & 6.942 & 7.214 \\
\hline$A I^{\mathrm{IV}}$ & 1.149 & 1.023 & 1.046 & 0.786 \\
\hline $\mathrm{Fe}^{+3}$ & 0.021 & - & 0.012 & - \\
\hline$z$ & B. 000 & 8.000 & B. 000 & 8.000 \\
\hline A) VI & - & 0.167 & - & 0.072 \\
\hline $\mathrm{Ti}$ & 0.264 & 0.191 & 0.227 & 0.108 \\
\hline $\mathrm{Fe}^{+3}$ & 0.462 & 0.419 & 0.336 & 0.361 \\
\hline $\mathrm{Fe}^{+2}$ & 2.489 & 2.286 & 2.438 & 2.330 \\
\hline $\mathrm{Mg}$ & 2.070 & 2.213 & 2.065 & 2.266 \\
\hline$M n$ & 0.091 & 0.073 & 0.091 & 0.099 \\
\hline$Y$ & 5.376 & 5.343 & 5.137 & 5.236 \\
\hline $\mathrm{Ca}$ & 1.512 & 1.505 & 1.820 & 1.716 \\
\hline $\mathrm{Na}$ & 0.374 & 0.410 & 0.291 & 0.262 \\
\hline K & 0.109 & 0.182 & 0.091 & 0.063 \\
\hline$x$ & 1.995 & 2.097 & 2.202 & 2.041 \\
\hline $\mathrm{OH}$ & 1.988 & 1.785 & 1.965 & 1,887 \\
\hline$\overline{m g}$ & 0.406 & 0.446 & 0.422 & 0.451 \\
\hline $\mathrm{Mg} / \mathrm{Fe}$ & +20.83 & 0.97 & 0.85 & 0.97 \\
\hline index & a 1.659 & 1.658 & 1.660 & 1.660 \\
\hline & $\gamma 1.678$ & 1.676 & 1.677 & 1.677 \\
\hline$K_{D}^{B i-1}$ & 0.76 & 0.73 & 0.91 & 0.76 \\
\hline
\end{tabular}

optical properties are tabulated in Table 3 .

Fig. 5 shows the relation between $\mathrm{Al}^{\mathrm{IV}}$ and $\left(\mathrm{Al}^{\mathrm{vI}}+\mathrm{Fe}^{+3}+\mathrm{Ti}\right)$ of analyzed hornblendes. The hornblendes fall within the common hornblende field. Following to decrease of $\mathrm{Al}^{\mathrm{rv}}$, the plotted points are aligned from the common hornblende field toward the tremolite end member. No Alvi or only small amount of $\mathrm{Al}^{\mathrm{lI}}$ was calculated in the hornblendes, as the same as the case in the coexisting biotites. $\mathrm{Mg} / \mathrm{Fe}^{+2}$ ratio ranges from 0.83 to 0.97 , and is larger than 


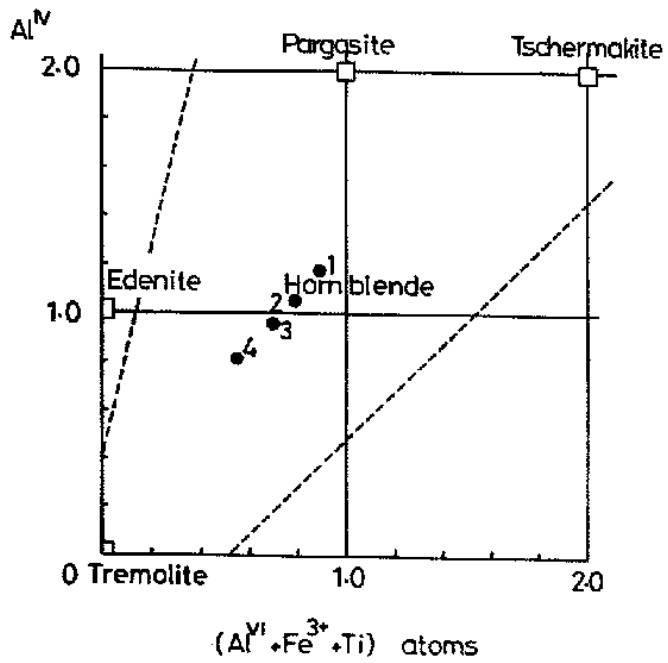

Fig. 5 Chemical variation of the calcium-rich amphiboles expressed as the numbers of $\left(\mathrm{Al}^{\mathrm{VI}}+\mathrm{Fe}^{+3}+\mathrm{Ti}\right)$ and $\mathrm{Al}^{\mathrm{IV}}$ atoms per formula unit.

that of the coexisting biotites. $\mathrm{Fe}^{+3} / \mathrm{Fe}^{+2}$ ratio $\left(0.13^{-0.19)}\right.$ of the hornblendes is approximately similar to that $(0.14-0.26)$ of the coexisting biotites. This fact may suggest that no change had occurred in the oxygen partial pressure in the magma during crystallization of coexisting hornblende and biotite.

\section{Distribution of $\mathrm{Fe}^{+2}$ and $\mathrm{Mg}$ in Coexisting Biotites AND Hornble- NDES}

Most of granitic rocks of the Okueyama granodiorite batholith have coexisting biotite and hornblende pairs. The distribution coefficients of $\mathrm{Fe}^{+2}$ and $\mathrm{Mg}, K_{D}=\left(X^{B^{i}} / 1-\right.$ $\left.X^{B i}\right) /\left(X^{H o r} / 1-X^{H o r}\right)$, in the analyzed biotite and hornblende pairs are listed in Table 3. Here, $X^{B^{i}}$ and $X^{H o r}$ are $\mathrm{Mg} /\left(\mathrm{Mg}+\mathrm{Fe}^{+2}\right)$ mole fractions of biotite and hornblende, respectively.

The distribution coefficient of the biotite and hornblende pair from the rock containing calcite, No. Oks-3, indicates a relatively higher value, but that of the other three pairs ranges from 0.73 to 0.76 . Kanisawa (1972) has shown that the distribution coefficient of $\mathrm{Fe}^{+2}$ and $\mathrm{Mg}$ in the biotite and hornblende pairs from granitic rocks in the Kitakami Mountainland, northeast Japan, is uniform in respective intrusive bodies. Judging from this, most of the Okueyama granodioritic rocks were equilibrated during formation of the batholith. The distribution coefficients of the analyzed biotite and hornblende pairs are similar to those from the Kitakami granitic rocks (Kanisawa, 1969, 1972; Kato, 1972, 1974; Kato and Tanaka, 1973, Kato et al. 1977, and Tanaka, 1975), but are smaller than those from the Ryoke granitic rocks of the Takato district, Central Japan (Kanisawa, 1975).

The $\mathrm{Mg} / \mathrm{Fe}^{+2}$ ratios of the analyzed biotites and homblendes from the okueyama granitic rocks are smaller than those from the Kitakami granitic rocks, while, those of the analyzed hornblendes are similar to those from the Ryoke granitic rocks (Kanisawa, 1975). The $\mathrm{Al}^{\mathrm{Iv}}$-content of the analyzed hornblendes is smaller in in amount than that of hornblendes from the Ryoke granitic rocks, but similar to that of hornblendes from the Kitakami granitic rocks. The Niggli's $m g$ values of the analyzed host granodiorites are higher as compared to those of the Kitakami and Ryoke rocks (Fig. 6). These facts indicate that either $\mathrm{Mg} / \mathrm{Fe}^{+2}$ ratio or $\mathrm{Al}^{\mathrm{Iv}}$-content or both in the hornblendes is not only affected by bulk composition of their host rocks, but also by physical conditions during crystallization of hornblende.

Fig. 6 shows a relationship between the $m g$ values of the coexisting biotites and hornblendes and those of their host granitic rocks. In the Kitakami granitic rocks, biotites rather than hornblendes are plotted 


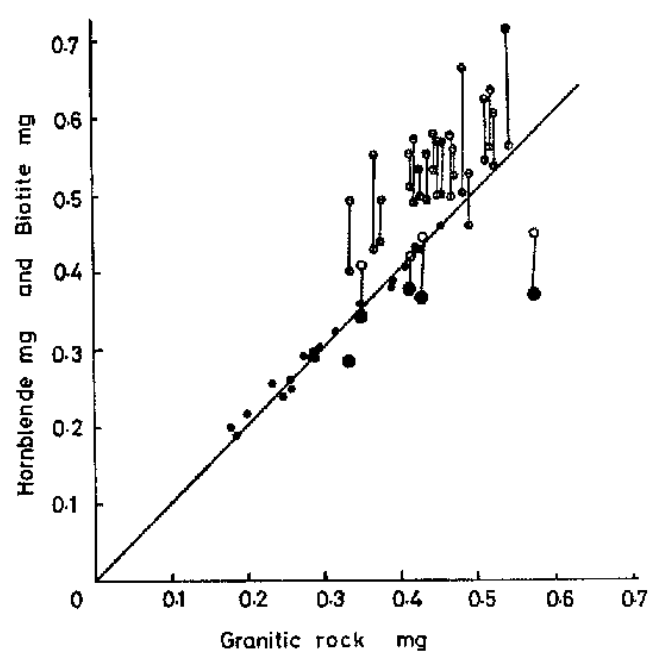

Fig. 6 Relationship between $m g$ values of coexisting biotites and hornblendes and those of their host granitic rocks. $\mathrm{O}$ : Hornblendes from the Okueyama granodiorite ; Biotites from the Okueyama granodiorite $\Theta$; Hornblendes from the Kitakami granitic rocks (1) Biotites from the Kitakami granitic rocks - Hornblendes from the Ryoke granitic rocks.

in an area near the 1:1 line, suggesting that the biotites are compositionally affected by the bulk composition. In the Ryoke granitic rocks, hornblendes are closely plotted on the same line, suggesting that the hornblendes are compositionally affected by the bulk composition. In the case of the Okueyama granodiorite, both the analyzed biotite and hornblende pairs fall in an area near the line, except for a pair No. Oks-4 which was affected by the residual liquid. These facts suggest that the chemical composition of both the biotites and hornblendes was controled on the bulk composition of host rocks in an earlier stage during the formation of the Okueyama batholith.

Kanisawa (1971) has reproted that the $\mathrm{Al}^{\mathrm{IV}}$ - and $\mathrm{Al}^{\mathrm{VI}}$-contents of hornblendes from granitic rocks associated with volcanic rocks in the Kitakami Mountainland are smaller in amount than those unassociated with volcanic rocks in other regions. Those of the analyzed hornblendes of the Okueyama batholith are also small. It is suggested, that hornblendes from granitic rocks which were formed in a state of the volcano-plutonic complex are poorer in the $\mathrm{Al}^{\mathrm{IV}}$-and $\mathrm{Al}^{\mathrm{II}}$-content as compared to those from granitic rocks without the activity of the volcano-plutonic complex.

\section{Gonclusion}

Chemical compositions of coexisting biotite and hornblende pairs and their host granitic rocks of the Shishigawa-type of the Okueyama granodiorite batholith were investigated in the present study. The batholith is apparently one which was formed by a volcano-plutonic complex activity, as reported by Hashimoto and Miyahisa (1959). The difference in chemical composition between granitic rocks of the southern part and those of the northern part in the batholith is characterized by the fact that the granitic rocks in lower elevation of the southern part are poorer in $\mathrm{SiO}_{2}$ than those in higher elevation of the northern part. It is suggested that the latter was affected by the residual liquid which was derived throughout differentiation of magma of the Okueyama granodiorite.

Chemical compositions of analyzed biotites and hornblendes indicate that both minerals are poor in $\mathrm{Al}$, and $\mathrm{Mg} / \mathrm{Fe}^{+2}$ ratios of these minerals are low in spite of the host granitic rocks have high Niggli's $m g$ value. The average distribution coefficient for $\mathrm{Mg}$ and $\mathrm{Fe}^{+2}$ of the coexisting biotite and hornblende pairs is 0.75 .

Chemical compositions of the analyzed biotites and hornblendes from the Okueyama granitic rocks were compared to 
those from the Kitakami and the Ryoke granitic rocks. As compared to the Kitakami granitic rocks, the analyzed biotites and hornblendes have the lower $\mathrm{Mg}$ / $\mathrm{Fe}^{+2}$ ratios, and the host rocks have the higher $m g$ value. On the other hand, as compared to the Ryoke granitic rocks, the analyzed hornblendes have the lower $\mathrm{Al}^{\mathrm{Iv}}$ content, and the host rocks have the higher $m g$ value. The compositional features of the analyzed biotites, hornblendes and host granitic rocks suggest that the Okueyama grandiorite would have been a product by a volcano-plutonic complex activity. Similar studies are expected to clarify the genesis of many granitic intrusive rocks containing both biotite and hornblende in the Outer Zone of Southwest Japan.

\section{ACKNOWLEDGEMENTS}

The writers are deeply grateful to Professor K. Yagi, Hokkaido University, for his valuable advice and critical reading of the manuscript. Thanks are also due to Dr. K. Tomita of the Kagoshima University for his kind guidance throughout this study.

\section{REFERENCES}

Foster, M.D. (1960), Interpretation of the composition of tri-octahedral micas. U.S. Geol. Surv, Prof. Pap., 354-B, 1-49.

Hashimoto, I. and Miyahisa, M. (1959), Stratigraphic sequence and geologic structure of the Tomiyama Peninsula, Miyazaki Prefecture -some problems concerning the geologic histry of the Shimanto terrain in Kyâshū. Rep. Geol., Fac. Geneval Eau. Kyūshü Univ., No. 6,

29-51 (in Japanese with English abstract).

Imai, I., Teraoka, Y. and Okumura, K. (1971), Geologic structure and metamorphic zonation of the northeastern part of the Shimanto terrane in Kyushu, Japan. Jour. Geol. Soc. Japan., 77, 207-220

IUGS Subcommission, (1973), Plutonic rocks, classification and nomenclature recommended by the IUGS subcommission on the systematics of igneous rocks. Geotimes, 18, 26-30.

Kanisawa, S. (1969), One the Hitokabe granodioritic mass, Kitakami Mountainland. Jour. Japan. Assoc. Min. Petr. Econ. Geol., 62, 275-288, (in Japanese with English abstract). (1972), Coexisting biotites and hornblendes from some granitic rocks in southern Kitakami mountains. Jour. Japan. Assoc. Min. Petr. Econ. Geol., 67, 332-344

(1974), Granitic rocks closely associated with the lower Cretaceous volcanic rocks in the Kitakami mountains, Northest Japan. Jour. Geol. Soc. Japan., 80, No. 8, 355-367. (1975), Chemical composition of hornblendes of some Ryoke granites, central Japan. Jour. Japan. Assoc. Min. Petr. Econ. Geol., 70, 200-211.

Kato, Y. (1972), Petrology of the Orikabe granitic body, Kitakami mountainland. Jour. Japan. Assoc. Min. Petr. Econ. Geol., 67, 50-59, (in Japanese with English abstract).

Japa (1974), Petrology of the Tabashine granitic body, Kitakami mountains, northern Japan. Jour. Japan. Assoc. Min. Petr. Econ. Geol., 69, 417-425.

Kinkasan granitic body, Kitakami mountains. Jour. Japan. Assoc. Min. Petr. Econ. Geol., 68, 395-403, (in Japanese with English abstract)

- Onuki, H., and Tanaka H., (1977), Compositional dependence of the $\mathrm{Mg} / \mathrm{Fe}^{2+}$ distribution coefficient between biotitehornblende pairs from calc-alkaline granitic rocks. Jous. Japan. Assoc. Min. Petr. Econ. Geol., 72, 252-258.

Kuroda, Y. (1948), Granites of Okueyama, Miyazaki Prefecture. Graduation Thesis of Inst.

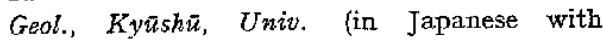
English abstract).

Miller, J.A., Shibata, K., and Kawachi, Y. (1962), Potassinm-argon ages of granitic rocks from the outer zone of Kyushu, Japan. Bull. Geol. Surv. Japan, 13, 712-714.

Miyahisa, M, Kinoshita, K. and Tomita, $T$. (1953), Genetic epoch of ore deposits associated with acidic intrusive in Kyushu Outer Zone. Jouy. Geol. Soc. Japan., 59, 309, (abstract in Japanese).

Nozawa, T. and Takahashi, K. (1960), On the petrochemistry of Shishigawa granite. Bull. Geol. Surv. Japan, 11, 489-502.

Öba, N. (1961), Contamination effect in Okueyama granite. Jour. Japan. Assoc. Min. Petr. Econ. Geol., 46, 119-127, (in Japanese with 
English abstract).

(1967), Granitic rocks in the western district of the Shimanto terrain, southwest Japan. Professor $H$. Shibata Memorial Volume, 34-40, ed. T. Sudo, Tokyo.

Tanaka, H. (1975), Magnesium-iron distribution in coexisting biotite and hornblende from gxanitic rocks. Jous. Japan. Assoc. Min. Petr. Econ. Geol., 70, 188-124.

Toriyama, T. (1936), On the satellitic bodies and the roof pendants with the Okueyama granite, Hyuga Country. Jour. Geol. Soc. Japan., 43, 377-381.

\section{大鹏山花風閃緑岩中の共存する黒雲母・角閃石の化学組成について}

大場孝信, 山本温彦, 大庭昇

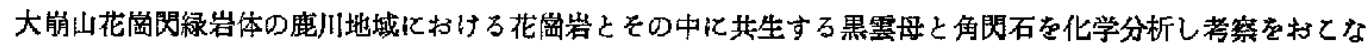
st。

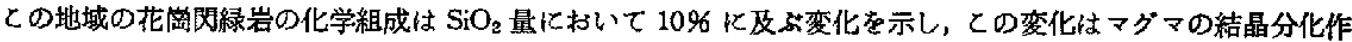
用によって生じたるのである。

花南閃緑岩中の黒零母と角閃石とも $\mathrm{Al}$ が少なく, $\mathrm{Mg} / \mathrm{Fe}^{+2}$ 比が小さい。 $\mathrm{Mg}$ と $\mathrm{Fe}^{+2}$ の平衡定数 $\mathrm{KD}^{\mathrm{Bi}-\mathrm{Hor}=}$

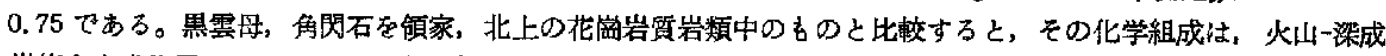
岩複合火成作用によってできた花南岩質岩類中のちのに近い。 